DOI: https://doi.org/10.3126/tgb.v6i0.26170

\title{
Socio-economic Background of the Women Workers in Guranse Tea Estate, Dhankuta
}

\begin{abstract}
Anita Thapa1
Abstract

Abundance of female workers in tea estate is common phenomena in the context of Nepalese tea industry. Women are main work force especially for leaf picking in any tea industry. So, the role of women participation is notable in this sector. This study focusses on socioeconomic background of women workers in Guranse Tea Estate, Dhankuta. Both qualitative and quantitative methods have been used to collect data and information through questionnaire, interview, focused group discussion, key informant interview and observation. Various types and nature of tea workers are found in the tea industry. Different types of socio-economic background such as caste/ethnicity, age group, educational status, land ownership, income level etc. have been found in this tea estate. Most of the workers are represented from indigenous and ethnic group with 20-40 age group. Similarly, a large number of tea workers are illiterate and landless as well as having low level of income.
\end{abstract}

Key words: Women worker, Guranse tea estate, tea plantation, participation, income Introduction

Tea is an important commercial cash crop in Nepal. Tea farming in Nepal has appeared as a significant agro-based industry that has been contributing vastly to the national economy in terms of generating employment opportunity as well as raising the revenue in the present days (Karki, 1981).

Tea plantation was started in 1863 from Ilam, its expansion in the real sense, took place only after the establishment of Nepal Tea Development Corporation Board (NTDCB) in 1966 when first Rana Prime Minister Janga Bahadur Rana came in power. Tea estate employs local people as permanent labor. It provides a huge number of employment opportunities for the local people as seasonal workers.

\footnotetext{
${ }^{1}$ Corresponding email: thapaanita87@gmail.com
} 
There is significant relationship between occupational pattern and existing socioeconomic condition of local people who are involved in tea industry. The role of women workers is significant to develop tea estate. is true because women are traditionally sound to the household responsibilities as carrying and raising children, cleaning house, washing clothes, cooking, and carrying water from the village tap etc. (Pokharel, 1989). Tea plantation is generally large-scale capitalistic enterprise having the nature of modern organized industry. They are often located in isolated places always from popular communities and dependent more upon migrated laborers, who live within the plantation area or in the vicinity (Chakravorty, 1997).

Tea plantation is labor-intensive, agro-based industry that employs a huge workforce involving both men and women, of which women workers constitute a great majority. One of the peculiar features of plantation workers is such that they mostly belong to tribal and indigenous communities having their own socio-cultural customs and practices who are almost illiterate poverty stricken, and backward (Kafle, 2000; Poudyal, 1999). In Nepal, it is found that major ethnic group of laborers such as Gurung, Tamang, Rai, and Subba are involved as labor of tea farming. These group constitute most dominating labor force in the tea estate in terms of number (Dahal, 2004; Sherpa, 2004). This study investigates socio-economic background of women workers of Guranse Tea Estate in Dhankuta district of Nepal.

\section{Methodology}

\section{Study area}

Dhankuta is one of the hilly districts of eastern Nepal. The study area is located in Dhankuta Municipality Ward No- 1, adjoins to Hile bazar which is a popular market center of eastern hill region. The relief of the Dhankuta is various from 120 meter to 2702-meter-high above the mean sea level (DDC, 2017). Guranse is situated at an altitude ranging from 1051 to 2200 meter above the sea level. It is situated between $26^{\circ} 35^{\prime}$ North to $27^{\prime} 19^{\prime}$ North Latitude and 87019' East to 87033' East Longitude. Warm-temperate type of climate is found in the study area. Soil is one of the most basic natural factors influencing for agricultural productivity. Most of the land of this area is suitable for tea cultivation. Now the farmers of this area are cultivating maize, millet, potato, cauliflower, cabbage and ginger as commercial crops and vegetable farming. They have cultivated cardamom where forest and dumpy area is available. Madan Bhandari Highway links this area nearby Hile. 


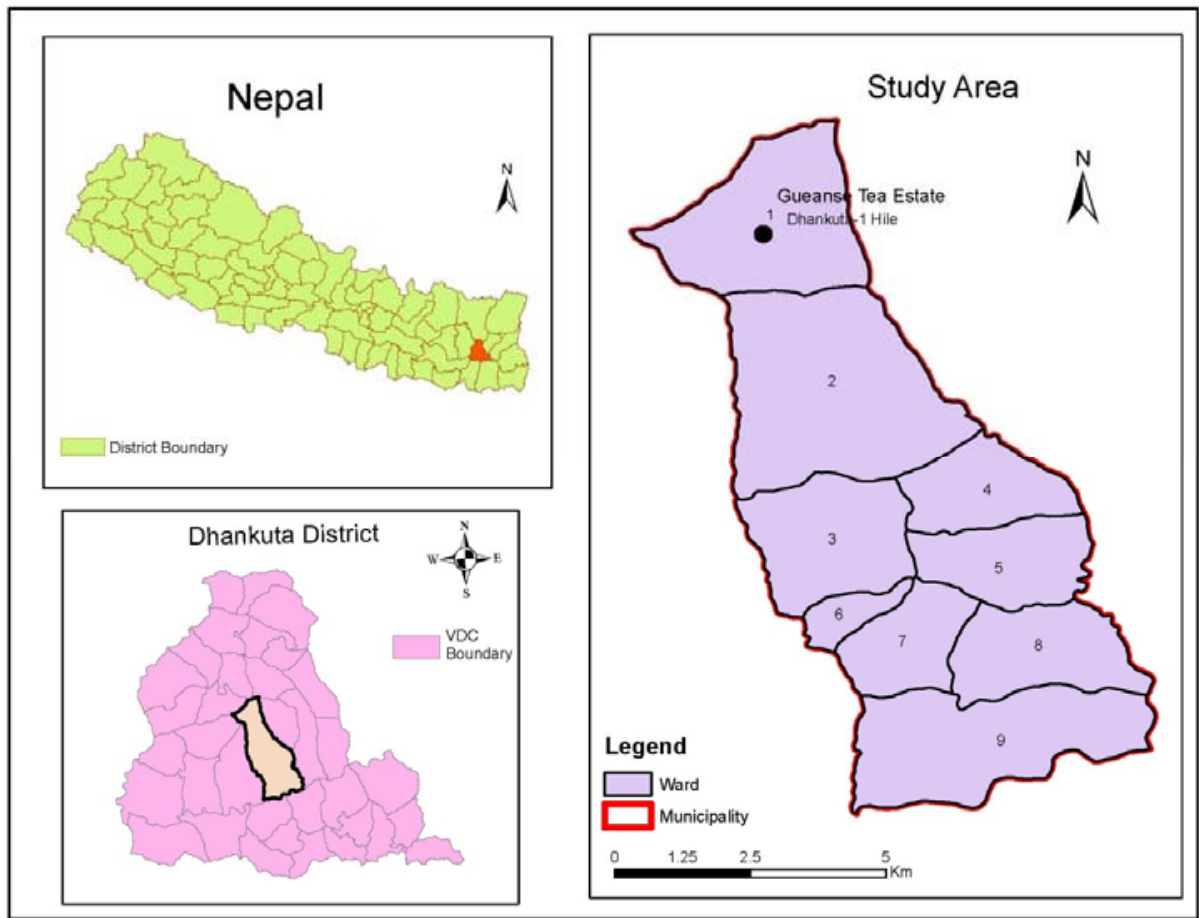

Figure 1: Location map of the study area

\section{Tools and techniques}

Basically, this study is based on the primary information collected from the field survey. The primary data were obtained through interview, observation, check list, group discussion official record of Guranse Tea Estate. Secondary information was obtained from journals, books, website and published and unpublished articles. Among 120 women workers, only 40 female respondents were taken in this study. The purposive sampling design was carried out representing different religion, caste, age group etc. By using purposive sampling method 35 percent or 14 Aryan respondent, 55 percent or 22 Mongol respondents' 10 percent or 4 untouchable respondents were selected as sample.

\section{Result and discussion}

\section{Caste/ ethnic background of workers}

There are different caste and ethnic group of participation in this tea estate such as Chhetri, Brahmin, Rai, Limbu, Newar, Tamang, Sherpa, Kami, Damai, etc. The following table shows the distribution of caste/ethnic group of the women worker in Guranse Tea Estate. 
The Geographic Base Vo. 6: 87-96, 2019

Table 1: Caste/ ethnic group of the workers

\begin{tabular}{|l|l|l|l|}
\hline SN & Caste/ethnic & No of worker & Percentage \\
\hline 1 & Brahmin & 4 & 10 \\
\hline 2 & Chhetri & 10 & 25 \\
\hline 3 & Rai & 6 & 15 \\
\hline 4 & Limbu & 3 & 7.5 \\
\hline 5 & Newar & 3 & 7.5 \\
\hline 6 & Sherpa & 4 & 10 \\
\hline 7 & Tamang & 6 & 15 \\
\hline 8 & Kami & 2 & 5 \\
\hline 9 & Damai & 2 & 5 \\
\hline & Total & $\mathbf{4 0}$ & $\mathbf{1 0 0}$ \\
\hline
\end{tabular}

Source: Field survey, 2016

The above table shows that 10 percent workers are Brahmin, 25 percent Chhetri, 15 percent Rai, 7.5 percent Limbu, 7.5 percent Newar, 10 percent Sherpa, 15 percent Tamang and 10 percent workers are untouchable group i.e. Kami and Damai. Out of the total workers, 55 percent are Mongolian group and 35 percent worker sare from Brahmin and Chhetri community and the lowest, 10 percent workers from Damai, Kami.

\section{Age distribution of workers}

Age distribution is an important part of our life, which affect the socioeconomic condition of women worker. The women have different role as daughter, daughterin-low, and mother-in-law in different age. They have different working capacity as different age group. Age distribution of the interviewed workers is given in Table 2.

Table 2: Age distribution of workers

\begin{tabular}{|l|l|l|l|}
\hline SN & Age (year) & No of worker & Percentage \\
\hline 1 & Below-20 & 1 & 2 \\
\hline 2 & $20-30$ & 10 & 25 \\
\hline 3 & $30-40$ & 12 & 30 \\
\hline 4 & $40-50$ & 11 & 28 \\
\hline 5 & 50 above & 6 & 15 \\
\hline & Total & $\mathbf{4 0}$ & $\mathbf{1 0 0}$ \\
\hline
\end{tabular}

Source: Field survey, 2016 
From the table, it is observed that the higher percentage of the respondents is under the age group of 30-40 and secondly the age group of 40-50. The main cause of this middle age group and younger age groups are more active and powerful as laborers for physical work, so they highly participated in this type of work.

\section{Educational status of workers}

Educational qualification is an important element of life for raising interest among people for improving their economic condition and for creating a healthy and clean environment. It also plays a vital role for the development of national economy as a whole. Education is the principle mechanism or agent for fulfilling the awareness and change of the people. It is vital indicator of women's social status and also the basic requirement of the nation

Table 3: Educational status of workers

\begin{tabular}{|l|l|l|l|}
\hline SN & Education & No of worker & Percentage \\
\hline 1 & Illiterate & 16 & 40 \\
\hline 2 & Informal education & 6 & 15 \\
\hline 3 & Primary level & 10 & 25 \\
\hline 4 & Secondary level & 8 & 20 \\
\hline & Total & $\mathbf{4 0}$ & $\mathbf{1 0 0}$ \\
\hline
\end{tabular}

Source: Field survey, 2016

The table three shows that the percentage of illiterate rate is 40 percent, who cannot able to read and write. Literacy rate is 60 percent who are able to read and write. In the comparison literate women workers are more than the illiterate women workers in this tea estate. Only 15 percent respondent women are literate who gained informal education, 25 percent respondents have gained primary level of education and 20 percent responding having secondary education. More wives are found illiterate in comparison of women with their husband. In this way, the educational status of women is lower than men. Although, they are illiterate, they have positive attitude towards education.

\section{Marital status of the workers}

Marital status is the important indicator of our social status. It is the most important event in the social life. According to Hindu tradition, marriage is a must for all whether men or women. Women status is different as married, unmarried, widow 
and divorce. They have different problem as married, unmarried, widow and divorced.

Table 4: Marital status of workers

\begin{tabular}{|l|l|l|l|}
\hline SN & Marital status & No of worker & Percentage \\
\hline 1 & Married & 35 & 88 \\
\hline 2 & Unmarried & 3 & 8 \\
\hline 3 & Widow & 1 & 2 \\
\hline 4 & Divorced & 1 & 2 \\
\hline & Total & $\mathbf{4 0}$ & $\mathbf{1 0 0}$ \\
\hline
\end{tabular}

Source: Field survey, 2016

The table four shows that 88 percent women respondents are married, 8 percent are unmarried, 2 percent are widow and only 2 percentages are divorce. This indicates that most of the women who were holding labor job were already married. It shows that most of the respondents are married. Most of the unmarried women workers are seasonal workers. According to this table we can say that the women have to play important role after marriage. There is the important role of married women for the 22 participation in the tea estate. The widow and divorced women have the problem to look after the family with their income.

\section{Occupation of the workers}

Since the size of family members is high and the employed number per family is very low, the wage they got is not sufficient to fulfill their requirements. The study found workers respondents and their families taking subsidiary occupation of the respondents is given in following table.

Table 5: Occupation of the workers

\begin{tabular}{|l|l|l|l|}
\hline S.N. & Occupation & No of worker & Percentage \\
\hline 1 & Tea industry labor & 18 & 45 \\
\hline 2 & Tea + agriculture & 10 & 25 \\
\hline 3 & Tea+ other & 12 & 30 \\
\hline & Total & $\mathbf{4 0}$ & $\mathbf{1 0 0}$ \\
\hline
\end{tabular}

Source: Field survey, 2016 
The above table shows that 45 percent worker has only the occupation as the tea industry labors. Similarly, 25 percent workers are involved in tea cum agriculture. Only few workers have their own land where they grow some food crops, vegetables and fruits for themselves. Similarly, 30 percent workers are involved in tea cum other miscellaneous occupations. It is found that husband, sons and other family members of workers, if not employed in the tea industry do their works such as: office, tailoring, shoe making and other daily wage labors.

\section{Land holding size of the workers}

Land is one of the factors by using it the women can rise their income. Who have land they should not depend only on the tea estate? They can involve in tea estate and agriculture. They have the residence in their own land. Their economic status depends on their land holding size. Land is necessary part of human beings. Land holding size of respondents' family is given below.

Table 6: Land holding size of the workers

\begin{tabular}{|l|l|l|l|}
\hline SN & Land size (Ropani) & No of worker & Percentage \\
\hline 1 & Landless & 20 & 50 \\
\hline 2 & $1-5$ & 12 & 30 \\
\hline 3 & $5-10$ & 4 & 10 \\
\hline 4 & $10-15$ & 3 & 7.5 \\
\hline 5 & 15 above & 1 & 2.5 \\
\hline & Total & $\mathbf{4 0}$ & $\mathbf{1 0 0}$ \\
\hline
\end{tabular}

Source: Field survey, 2016

Women who have more land have good income. The landless women worker has job opportunity only in tea estate. They are compelled to work in the estate although they are not satisfied. Their income is not enough for their daily livelihood sustaining. They are not able to spend money for their children education.

\section{Monthly income}

The economic condition of women worker depends on the income. According tothe respondents, they are given Rs.253 per day. It means they saved Rs.7990 per month for their actual salary. But they work overtime sometimes too. Thursday is holiday in a week. They don't get money for the holiday. Sometimes it is increased and sometime it is decreased. If they pluck more than fixed margin, they get Rs.10 per kg. 
The Geographic Base Vo. 6: 87-96, 2019

Table 7: Monthly income family

\begin{tabular}{|l|l|l|l|}
\hline SN & Income & No of worker & Percentage \\
\hline 1 & $<5000$ & 6 & 15 \\
\hline 2 & $5000-7000$ & 18 & 45 \\
\hline 3 & $7000-10000$ & 10 & 25 \\
\hline 4 & $10000-12000$ & 4 & 10 \\
\hline 5 & $>12000$ & 2 & 5 \\
\hline & Total & $\mathbf{4 0}$ & $\mathbf{1 0 0}$ \\
\hline
\end{tabular}

Source: Field survey, 2016

The table seven shows that the monthly income of the respondents. The highest 15 percent worker has less than Rs.5000 monthly income. Only 5 percent workers have more than Rs. 12000 monthly income. Most of the respondents have low income because they have very low salary and most of them have only tea as income source. Only a few women have more than Rs.12000 monthly income. Those who have land and hence their income is high because of agriculture works.

\section{Monthly expenditure}

Table 8: Monthly family expenditure

\begin{tabular}{|l|l|l|l|}
\hline SN & Expenditure (NRs) & No of worker & Percentage \\
\hline 1 & $>5000$ & 2 & 5 \\
\hline 2 & $5000-7000$ & 5 & 12.5 \\
\hline 3 & $7000-10000$ & 8 & 20 \\
\hline 4 & $10000-12000$ & 15 & 37.5 \\
\hline 5 & $12000>$ & 10 & 25 \\
\hline Total & Total & $\mathbf{4 0}$ & $\mathbf{1 0 0}$ \\
\hline
\end{tabular}

Source: Field survey, 2016

The table eight shows that the highest 37.5 percent worker has Rs. 1000012000 monthly expenditure as reported by the respondents. Only 5 percent workers have more than 5000 monthly expenditure. The income condition of women depends on the expenditure of the family. Comparing the income and expenditure, it shows that the women workers are having very poor standard of living. The price of the daily necessary goods is rising day by day, it has created challenge for the purchasing 
power of workers. So that all workers are suffering from the imbalance of income, expenditure and saving. This condition is harmful for peaceful living. Because if perperson income is low and expenditure is high in comparison with they could not save enough money. It affects their family income and hence the nation's economy. Tea cultivation has contributed to grow economic status of women of Guranse area in Dhankuta to some extent.

\section{Conclusion}

Socio-economic background of the workers is also an important aspect of any industry. The dominant number of female workers is common phenomenon in the tea estate. In Guranse Tea Estate, women participation is remarkable associated with different socio-economic background. Most of the women depend upon tea estate for their livelihood sustaining. More than half (55\%) labors are from with various ethnic groups such as Tamang, Sherpa, Rai and Limbu. Most of the workers are illiterate, landless, low income, married and below forty age. The highest 45 percent workers have only one occupation as the tea estate labors. The tea estate has employed a large number of local people as permanent as well as seasonal workers. The socio-economic condition of the female workers appears to be not much satisfactory as their level of income is low and their family size is large. Thus, in order to improve the living standard of the workers, policies and programs should be made by the government and tea estate authority itself. The facilities such as school, hospital, quarter and drinking water should be established nearby the estate for the wellbeing of the workers.

\section{References}

Dahal, S. (2004). Women labor participation in tea estate: A case study of women workers in Thimi Tea Estate of Sikkim, India. A Dissertation Submitted to the Central Department of Economies, Faculty of Humanities and social science T.U., Kathmandu.

DDC.(2017). District profile of Dhankuta District. Dhankuta: DDC.

Kafle, P.K. (2000). Women Workers in Tea Estate. A Dissertation Submitted to the Department of Sociology/Anthropology T.U., Kathmandu.

Karki, S. (2001). Women's contribution to tea industry in Nepal: A case study of women labors in Ilam tea industry, Ilam.A Dissertation Submitted to the Central Department of Economies, Faculty of Humanities and social science T.U., Kathmandu. 
The Geographic Base Vo. 6: 87-96, 2019

Chakraorty, R.N. (1997) Socio-economic development of plantation workers in North East India. Dibrugarh, Asam.

Poudyal, M.P. (1999). A study on socio-economic aspect of the tea workers in

Nepal.A Dissertation Submitted to the Department of Sociology/Anthropology T.U., Kathmandu.

Sherpa, P. (2004). Socio-economic condition, participation and impact of women workers on the tea estate. A sociological case study of Kanyam Tea Estate, A Dissertation Submitted to the Department of Sociology/Anthropology Patan Multiple Campus, Lalitpur 